\title{
EFFICIENGY ANALYSIS OF THE BANKS OPERATING IN TURKEY WITH AHP BASED ON DEA METHOD
}

\author{
Adem Babacan $^{1 *}$, Şahin Bulut ${ }^{2}$ and Neslihan Koç ${ }^{3}$ \\ ${ }^{1)}$ Sivas Cumhuriyet Üniversitesi, Sivas, Turkey \\ ${ }^{2}$ Aydin Adnan Menderes Üniversitesi, Aydin, Turkey \\ ${ }^{3)}$ Hitit Üniversitesi, Çorum, Turkey
}

Please cite this article as:

Babacan, A., Bulut, S. and Koç, N., 2020. Efficiency

Analysis of the Banks Operating in Turkey with AHP based on DEA Method. Amfiteatru Economic, 22(55), pp. 882-903.

Article History:

Received: 25 March 2020

Revised: 9 May 2020

Accepted:1 July 2020

DOI: $10.24818 / \mathrm{EA} / 2020 / 55 / 882$

\begin{abstract}
In this study, performance and its basic concepts, efficiency, and productivity, are explained and performance measurement methods are discussed.

The Analytical Hierarchy Process (AHP) was used to measure efficiency in multi-criteria problems and to determine the weights of criteria for efficiency measurement.

With the help of the Data Envelopment Analysis (DEA), which is one of the best methods of measurement of efficiency, efficiency levels of the banks in Turkey, whose data can be fully reached, was evaluated. The criteria for bank efficiency were weighted with the AHP and then the efficiency scores of the banks were determined using the Weighted DEA method. Potential improvements have been proposed for inefficient banks.
\end{abstract}

Keywords: performance, efficiency, Data Envelopment Analysis (DEA), Analytical Hierarchy Process (AHP), efficiency of banks in Turkey.

JEL Classification: G21, C14, C6.

* Corresponding author, Adem Babacan - ababacan1@ hotmail.com 


\section{Introduction}

In an economic world that requires unlimited resources to be met with limited resources, productive and efficient use of resources have great importance for every sector. Businesses use their existing resources efficiently and increase the rate of profit and achieve the targeted performance. The main objective of the firms is to achieve more output with less resources. Businesses increase their resources and expand their market share to reach a wider customer base and increase their profits. Appropriate resource use should be ensured so that decisions can affect performance positively.

The rapidly increasing competitive environment in the world has a significant impact on the banking sector. Therefore, the concept of efficiency has become much more important in the banking sector. Today, with the increasing competition in the Turkish banking sector, banks have had to use their resources in the most efficient way. As the being effective also makes it compulsory to be competitive, effective resource use has become important in the banking sector. Similarly, Berger (2007) notes that the performance of inefficient banks will be lower (Berger, 2007, p. 200).

Banks are intermediary institutions that allocate the obtained deposits to their customers through loans and carry out various transactions related to capital and credit for profit. They seek public interest in terms of the services they offer to their customers and contribute to the increase of national income and the development of the global economy. Branches are distribution channels that serve the purpose of reaching existing and potential customers of the banks and are the areas where customers can directly benefit from the service provided (Başar, Kabak and Topçu, 2015, p.3).

The banking sector is one of the most important institutions for the economic development. Banks have an important role in the economy by increasing capital and protecting its value, growth of firms and providing economic power. A strong and profitable banking system leads to financial stability. Levine's (1997) study also shows that financial intermediation affects economic growth. Changes in macroeconomic conditions also affect performance of a banking system and financial stability. Therefore, authorities responsible for ensuring financial and monetary stability should be aware of the impact of macroeconomic developments on the banking sector (Taşkın 2011, p.289).

Productive and efficient operation of the banking sector of Turkey is of paramount importance for the national economy because banking sector unlike other economic sectors plays the role of financial intermediation, which determines the allocation of resources. Therefore, efficiency and productivity rates should be known to make performance analysis in the banking sector.

In this study, performance, productivity, and efficiency are defined and the importance of these concepts are discussed. Then, available criteria used to measure the efficiency of banks in Turkey were determined and weighted. Afterwards, efficiencies of the banks were evaluated by using the Data Envelopment Analysis, which is a performance evaluation method without a parameter.

The purpose of this study is to measure financial efficiency of 18 banks in Turkey for the years between 2008 and 2017. Four inputs and six outputs were used in the analysis. Inputs and outputs were taken as criteria and weighted in line with the estimations of bank managers in Sivas with the help of the Analytic Hierarchy Period (AHP). Efficiency 
analysis was made using these weighted inputs and outputs via the DEA. For inefficient banks, the ideal ratio of inputs and outputs was calculated, and potential improvement suggestions were made for banks to become efficient.

\section{Analytic Hierarchy Process}

The analytic hierarchy process (AHP) was first proposed by Myers and Alpert in 1968 and developed by Thomas L. Saaty to solve complex problems, making it a widely used method in decision-making problems in 1977. AHP, which gives the weight of the decision criteria in terms of the factors affecting the decision, is a multi-criteria decision-making method used when the decision hierarchy can be defined.

In the application of the AHP, it measures how important and preferred criteria and alternatives are by making pairwise comparisons based on the assumption that an underlying element affects an upper element. AHP can be defined as a method of synthesizing the components and variables of a complex and unstructured situation in a hierarchical order, assigning quantitative values to the personal judgments regarding the comparative significance levels of each alternative and synthesizing the priority levels of the variables according to the result of the judgments obtained (Alp and Gündoğdu, 2012, p.10).

To solve a problem with the AHP method, the process steps indicated in the flowchart shown in Figure no. 1 are applied (Özbek and Tamer, 2012, p.49).

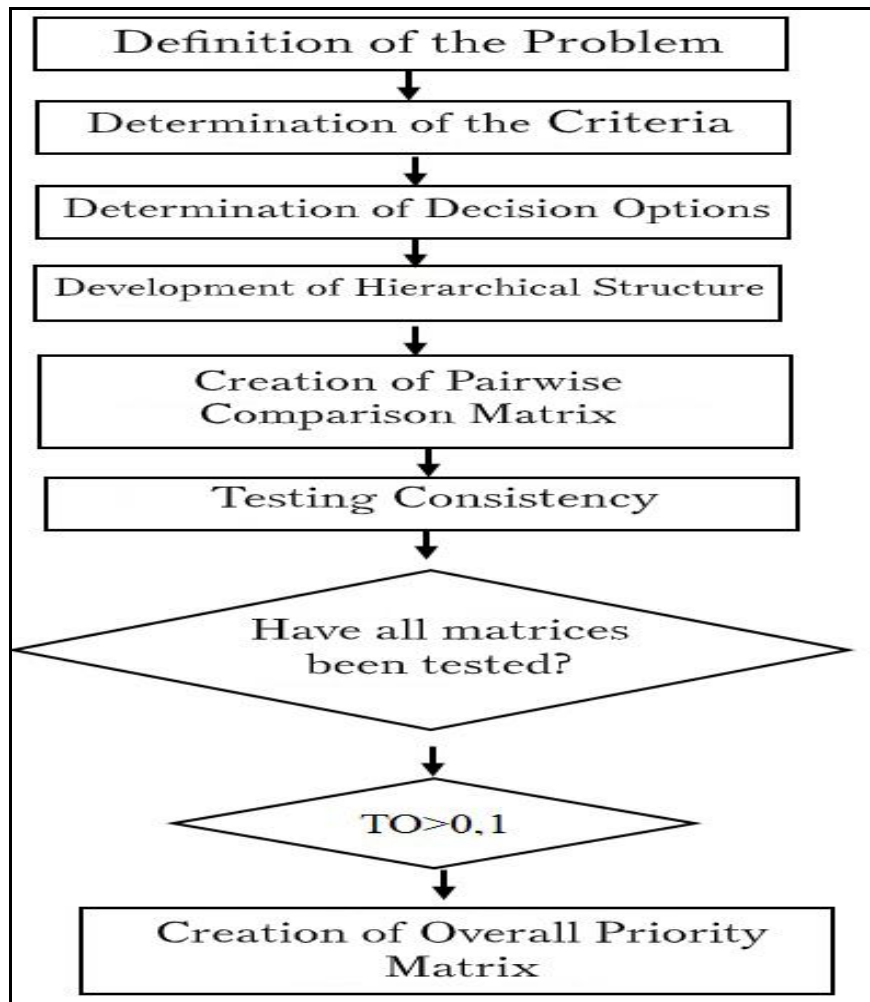

Figure no. 1. Flow chart 
Using a decision hierarchy, the AHP is based on one-to-one comparisons using the predefined comparison scale given in Table no. 1 both in terms of the factors affecting the decision and the significance of decision points for these factors. As a result, differences in importance turn into percentage distribution over decision points.

Saaty (1982) defined the absolute scale in addition to the previously known nominal, ordinal, interval and ratio scales for binary comparisons. In this scale, $x$ is constant under $\mathrm{x}=\mathrm{x}$ identity transformation. Saaty developed the following scale using the proposition of Stanislas Dehaene (1997), a mathematician and a cognitive neuropsychologist, in his book The Number Sense Introspection, which claims that human beings can attribute precise values mentally via numbers from 1 through 9 .

Table no. 1. Significance level table used in comparison

\begin{tabular}{|c|l|l|}
\hline $\begin{array}{c}\text { Significance } \\
\text { Degree }\end{array}$ & \multicolumn{1}{|c|}{ Description } & \multicolumn{1}{c|}{ Description } \\
\hline $\mathbf{1}$ & Equally Important & Both factors have the same importance. \\
\hline $\mathbf{3}$ & Moderately important & $\begin{array}{l}\text { Where the first criterion is more } \\
\text { important than the second criterion }\end{array}$ \\
\hline $\mathbf{5}$ & Strongly Important & $\begin{array}{l}\text { Where the first criterion is much more } \\
\text { important than the second criterion }\end{array}$ \\
\hline $\mathbf{7}$ & Strongly Important & $\begin{array}{l}\text { The first criterion is very strong } \\
\text { compared to the second criterion }\end{array}$ \\
\hline $\mathbf{9}$ & Absolutely Important & $\begin{array}{l}\text { The first criterion is of absolute } \\
\text { superiority to the second criterion }\end{array}$ \\
\hline $\mathbf{2 , 4 , 6 , 8}$ & Represents Intermediate Values & $\begin{array}{l}\text { Intermediate values (available when } \\
\text { needed). }\end{array}$ \\
\hline $\begin{array}{l}\text { Mutual } \\
\text { Values }\end{array}$ & $\begin{array}{l}\text { If a value }(x) \text { is assigned when comparing } \mathrm{i} \text { with } \mathrm{j}, \mathrm{j} \text { will be the value }(1 / \mathrm{x}) \text { to } \\
\text { be assigned when comparing with } \mathrm{i} .\end{array}$ \\
\hline
\end{tabular}

Source: Saaty, 1982, p.78

After the formation of the hierarchical structure, each criterion, and matrices of pairwise comparisons of alternatives for each criterion are formed.

$A=\left[\begin{array}{llll}a_{11} & a_{12} \cdots & a_{1 n} \\ a_{21} & a_{22} \cdots & a_{2 n} \\ a_{n 1} & a_{n 2} \cdots & a_{n n}\end{array}\right]_{n x n}$

$\left(a_{i j}\right)$ The comparison value between the two criteria / factor is ordered from $\mathrm{i}$ to factor $\mathrm{j}$ as

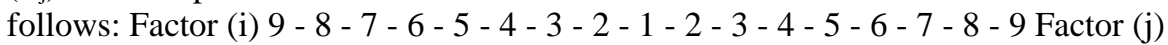

If the binary comparison matrix $\mathrm{A}$ is to be formed with the help of judgments given by more than one expert, the geometric mean of these judicial ratings should be taken. The generated comparison matrix is normalized and de-unitized. It is calculated with the following formula:

Anorm $=\left[b_{i j}\right]_{n x n}$ if $b_{i j}=\frac{a_{i j}}{\sum_{i=1}^{n} a_{i j}}$

$b_{\mathrm{ij}}$ 's indicate importance value of factor / criteria compared to each other. Due to normalization, the total of column is 
$A_{n o m}=\left[\begin{array}{cccc}b_{11} & b_{12} & \ldots & b_{1 n} \\ b_{21} & b_{22} & \ldots & b_{2 n} \\ \vdots & \vdots & \ldots & \vdots \\ b_{n 1} & b_{n 2} & \ldots & b_{n n}\end{array}\right]_{n x n}$

After the normalized matrix is created, the priority vector is calculated. The column vector $\mathrm{W}$, called the priority vector, is obtained. The priority vector is the core vector. The priority vector is calculated as follows:

$W=\left[\begin{array}{c}w_{1} \\ w_{2} \\ \vdots \\ w_{n}\end{array}\right] \quad$ and $w_{i}=\frac{\sum_{j=1}^{n} b_{i j}}{n}$

Here $w_{i}$ is the average of the total line of the normalized matrix $\left(\mathrm{A}_{\text {norm }}\right)$. Due to this normalization, the sum of all elements of the priority vector is $\sum w_{i}=1$. The priority vector expresses the importance weights of the criteria. While $\mathrm{w}$ is the weight of criterion 1 , $\mathrm{w}_{\mathrm{n}}$ is the weight of criterion $\mathrm{n}$. In fact, these weights are scale ratio. It shows that out of these ratios, we prefer criterion 1 over criterion 2 at the rate of $\frac{w_{1}}{w_{2}}=t$.

The final step is to check the consistency of the comparison matrix. Consistency, one of the important concepts of AHP, measures the consistency and consistency ratio of the comparison. When performing binary comparisons, inconsistent situations can occur as there is no objective ratio or measure whose accuracy was checked and also because the components are involved in multiple comparisons. An error that can be made in binary comparison matrices will lead to other subsequent errors and consequently to an inconsistent result.

Consistency index (CI) and Consistency ratio (CR) are used for consistency analysis. If the $\mathrm{CR}$ rate is less than or equal to $10 \%$, the level of non-compliance is considered sufficient and the model is considered to be compliant. If it is greater than $10 \%$, the level of noncompliance is not accepted and the decision matrix is re-evaluated.

To calculate the consistency ratio, initially the weighted sum of the elements in the columns is calculated for each row of the comparison matrix. The value in each column of the comparison matrix is then divided by the weight of the total column to find the normalized matrix and the Priority Vector is calculated by averaging each row of this normalized matrix. This vector is multiplied by the comparison vector to form the All Priorities Matrix that takes into account the comparison matrix. CI and CR, which is the consistency ratio, are calculated by the following formula.

$C R=\frac{G I}{R I}$

Here the CI consistency index is:

$C I=\frac{\lambda_{n n a x}-n}{(n-1)}$

Here $\lambda_{\max }$ represents the largest value among the eigenvalues of a square matrix. 
RI is called the Random Consistency Index and is used in the transactions by selecting the appropriate value from the values given in Table no. 2 .

Table no. 2. Random consistency index table

\begin{tabular}{|l|c|c|c|c|c|c|c|c|c|c|c|}
\hline $\begin{array}{l}\text { Decision Alternatives } \\
\text { number (n) }\end{array}$ & 1 & & 2 & 3 & 4 & 5 & 6 & 7 & 8 & 9 & 10 \\
\hline $\begin{array}{l}\text { Random Value } \\
\text { Index (RI) }\end{array}$ & 0 & & 0 & 0.52 & 0.89 & 1.11 & 1.25 & 1.35 & 1.40 & 1.45 & 1.49 \\
\hline
\end{tabular}

\section{Data Envelopment Analysis}

Farrell, in his original work "The Measurement of Productive Efficiency" in 1957, focused on the concepts of efficiency and efficiency measurement and formed the theoretical basis of DEA. This study by Farrell has revealed new approaches on efficiency at micro level and production efficiency (Dikmen, 2008, p.5).

As a continuation of Farrell's work, Boles (1996) and Afrait (1972) made some suggestions based on mathematical programming to determine the production boundary. However, these recommendations did not attract much attention (Çaymak, Ş. and Çaymak, D., 2017, p.36).

Data envelopment analysis was first developed by Charnes, Cooper and Rhodes in 1978, based on the frontier analysis proposed by Farrell. It was then used in many non-profit organizations and fields for efficiency analysis. The study, published by Charnes, Cooper and Rhodes, has taken its place in the literature as a CCR model. The CCR model assumes a constant return according to the scale (Charnes, Cooper and Rhodes, 1978). Data Envelopment Analysis is a linear application compatible with the economic theory of production, which allows to measure relative total factor efficiency when there are goods and services (inputs) and production (output) with different units that cannot be reduced to a common criterion (Çingi and Güran, 2002, p. 64).

DEA, which first emerged with the CCR model in 1978, showed differences with the BCC model, Additive model, and Slack-based efficiency measurement (SBM) in the following years. In this study, CCR and BCC models will be discussed.

\subsection{CCR Model}

In this model, it is assumed that there are n Decision Making Units (DMUs) and that each DMU has $m$ different inputs and $s$ different outputs. $\mathrm{KVB}_{\mathrm{j}} \mathrm{x}$ from the input $\mathrm{i}_{\mathrm{ij}}$ consuming quantity of input $\mathrm{r}_{\mathrm{rj}}$ produces quantity output. Another acceptance is that $\mathrm{x}_{\mathrm{ij}} \geq 0$ and $\mathrm{y}_{\mathrm{rj}} \geq 0$ and the main assumption is that at least one input and at least one output of each DMV have a positive value

DEA is form of ratio suggested by Charnes and Cooper (1962). This form involves the input-output ratio used to measure the relative efficiency of $\mathrm{DMUj}=\mathrm{DMUo}$. Here, $\mathrm{KVBo}$, KVBj s are tried to be measured in optimization and $\mathrm{o}=1,2, \ldots \mathrm{n} ; \mathrm{j}=1,2 \mathrm{n}$. The CCR is a 
structure that reduces many inputs and many outputs to one virtual (which exists in reality but not by name) input and one virtual output. The single virtual input-output ratio for a custom DMM provides an efficiency measure. This is a multiple function. In mathematical programming language, this ratio is the maximized form of the objective function of a particular DMU.

$\max h_{o}(u, v)=\frac{\sum_{r} u_{r} y_{r o}}{\sum_{i} v_{i} x_{i o}}$

Here $\mathrm{u}_{\mathrm{r}}$ and $\mathrm{v}_{\mathrm{I}}$ are weights and $\mathrm{y}_{\mathrm{ro}}$ and $\mathrm{x}_{\mathrm{io}} \mathrm{s}$ are the observed outputs and inputs, respectively. DMU is the evaluated DMU.

A set of normalized constraints indicates that the ratio of virtual output and virtual input of each DMU will be equal to or less than 1 . The objective function is to get weights of $\mathrm{v}_{\mathrm{i}}$ and $\mathrm{u}_{\mathrm{r}}$, which will maximize the productivity ratio for DMUo. In addition, all inputs and outputs cannot have negative values. Mathematical programming problem can also be expressed as follows:

$$
\begin{aligned}
& \frac{\sum_{r} u_{r} y_{r j}}{\sum_{i} v_{i} x_{i j}} \leq 1 \\
& \mathrm{u}_{1}, \mathrm{u}_{2}, \ldots, \mathrm{u}_{\mathrm{r}} \geq 0 \\
& \mathrm{v}_{1}, \mathrm{v}_{2}, \ldots \mathrm{v}_{\mathrm{i}} \geq 0 .
\end{aligned}
$$

The symbols used in the model are defined as follows:

$x_{i o}$ The amount of input "I"th of the decision-making unit "o", whose efficiency is measured,

$y_{r o}$ : The "r"th output amount of the decision-making unit "o", whose efficiency is measured,

$x_{i j}$ : the amount of input it used by the $\mathrm{j}$ decision making unit,

$y_{r j}:$ the amount of output $\mathrm{r}$ used by the $\mathrm{j}$-decision-making unit,

$u_{r}$ : factor weight given to the input "r" by decision-making unit "o",

$v_{i}$ : factor weight given to the input "i" by decision-making unit "o". 
The fractional programming model given in the maximization equation of the objective function is solved separately for each decision unit. In $\mathrm{n}$ optimization problem, the constraints will remain the same but the objective function will change. Within the solution of the problem, each decision unit determines the weights that will maximize their total factor productivity and these weights can be shown as follows: for inputs $v_{1 k}^{*}, v_{2 k}^{*}, \ldots v_{m k}^{*}$ and for outputs $u_{1 k}^{*}, u_{2 k}^{*}, \ldots u_{s k}^{*}$.

In DEA, this weighting is important in the solution of the model. In this study, AHP will be used to find weights. The lack of weighting in many articles is not a deficiency of DEA. Problems that are solved without weighting are highly likely not to yield accurate results. Then, using these calculated weight values, $\theta^{*}$, which is the optimum efficiency value, is obtained. $\theta^{*}$ optimum efficiency value cannot exceed 1 due to constraints. If $\theta^{*}$ is calculated as 1 , the decision making unit to which it belongs is regarded to be efficient; if it is calculated to be less than 1 , it is decided that the decision-making unit to which it belongs is inefficient.

Equivalent to the fractional programming model described so far is the linear programming model, which will be explicated below. Linear programming can be easily solved with the help of simplex algorithm. Therefore, it is preferred to fractional programming. In this transformation, the denominator (below) of the objective function is used after normalization.

$$
\sum_{i=1}^{m} v_{i} x_{i o}=1
$$

As a result of the operations, linear programming has the following form:

$$
\max z=\sum_{r=1}^{s} \mu_{r} y_{r o}
$$

Subject to

$$
\begin{array}{ll}
\sum_{i=1}^{m} v_{i} x_{i o}=1 & \begin{array}{c}
j=1, \ldots, n \\
(11) \\
\sum_{r=1}^{s} \mu_{r} y_{r j}-\sum_{i=1}^{m} v_{i} x_{i j} \leq \mathbf{O}
\end{array} \\
\mu_{r}, v_{i} \geq 0, & r=1, \ldots, s \quad ; \quad i=1, \ldots, m
\end{array}
$$

For example, if the number of constraints is high, it is necessary to examine the dual form as it reduces the number of constraints in the given mathematical model. This Dual model is as follows. 
$\theta^{*}=\min \theta$

Subject to

$$
\begin{array}{ll}
\sum_{j=1}^{n} x_{i j} \lambda_{j} \leq \theta x_{i o} & i=1, \ldots . ., m \\
\sum_{j=1}^{n} y_{r j} \lambda_{j} \geq y_{r o} & r=1, \ldots . ., s \\
\lambda_{j} \geq 0 & j=1, \ldots . ., n
\end{array}
$$

This latest model is also called the CR CCR Model. The CCR model is implemented in two ways. First one is called the input-oriented model and it aims to minimize inputs to meet the least observed output level. Secondly, the CCR is called as output-oriented model and maximize outputs so as not to demand more than the observed inputs.

\subsection{BCC Model}

With the BCC model developed by Banker, Charnes and Cooper and named with the initials of their names, the efficiency frontier is calculated in the variable return condition according to the scale and variable efficiency is taken into account. Thus, total efficiency is divided into technical efficiency and scale efficiency and the total efficiency value is obtained as a result of multiplying technical efficiency and scale efficiency. Therefore, a DMU is considered to be totally efficient only if both the technique is efficient and the scale is efficient. If the technique is inefficient or the scale is inefficient or the CVD carrying both conditions is considered totally inefficient, the total is considered inefficient. It is clear that the use of main resources will bring total efficiency in the implementation of the BCC model (Liu, 2007, p. 39).

In the BCC model, in envelope form according to the CCR model $\sum_{j=1}^{n} \lambda_{j}=1$, For each $j$ is a $\lambda_{j} \geq 0$ constraint. In the multiplier model, there is a variable like $\mu 0$ different from the BCC model. The relationship between the efficiency value of the CCR model and the

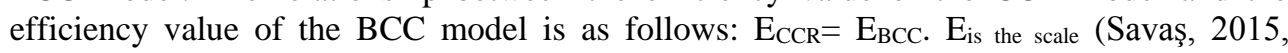
p. 215).

Unlike CCR models, BCC models operate under the assumption of variable cycling scale, not constant scale.

The optimal solution set of a BCC model is $\left(\beta_{\mathrm{B}}{ }^{*}, \lambda^{*}, \mathrm{~s}^{-*}, \mathrm{~s}^{+*}\right)$. Here $\mathrm{s}^{-*}$ is maximum input surplus, $\mathrm{s}^{+*}$ represents the maximum lack of output. If $\beta_{\mathrm{B}}=1$ and s $\mathrm{s}^{-*}=\mathrm{s}^{+*}=0$ requirements are met $\mathrm{DMU}_{0}, \mathrm{BCC}$ is efficient, if they cannot be met, $\mathrm{BCC}$ is inefficient.

A set of references to form the basis for improvement for an inefficient DMU, with the help of the results obtained from the first and second stage applications, which maximize free variable values;

$\mathrm{E}_{0}=\left\{\mathrm{j} \mid \lambda_{\mathrm{j}}^{*}>0\right\}(\mathrm{j} \varepsilon\{1, \ldots, \mathrm{n}\}) .>$ 
Optimal solution is as follows:

$$
\begin{gathered}
\beta^{*} \mathrm{x}_{0}=\sum_{j \in E_{0}} \lambda j^{*} x_{j}+s^{-^{*}} \\
\mathrm{y}_{0}=\sum_{j \in E_{0}} \lambda j^{*} y_{j}-s^{+^{*}}
\end{gathered}
$$

For each DMU, the "virtual output" and "virtual input" ratio should not exceed 1 in the restrictions. The aim is to evaluate the DMUs by maximizing the ratio of input and output weights of DMU. Then, to achieve efficiency by improving the input and output amounts in ${ }_{0}$, DMU can reach the efficiency frontier of point $\mathrm{x}$, yo 0 , which are known to be $\mathrm{BCC}$ projection, with the following transformation.

$\mathrm{x}_{0}^{\prime}=\beta_{\mathrm{B}} * \mathrm{x}_{0}-s^{-*}$

$\mathrm{y}^{\prime}{ }_{0}=\mathrm{y}_{0}+\mathrm{s}^{+^{*}}$

As a result of this projection, the ( $\left.\mathrm{x}_{0}^{f} \mathrm{y}^{\prime}{ }_{0}\right)$ point is obtained, which means $\mathrm{BBC}$ is efficient.

\section{Application}

In the application, to measure the efficiency of the banks in Turkey data from the annual financial statements were used. Three inputs and six outputs were used to measure efficiency. For this purpose, a questionnaire was applied to the managers of the banks in Sivas province in order to make the weightings and the inputs and outputs affecting the bank performance determined as a result of the judgments obtained were weighted with AHP method. These weights were then in the DEA method to measure efficiency. In the first part of the application, AHP hierarchy criteria were determined and established as presented in Figure no. 2.

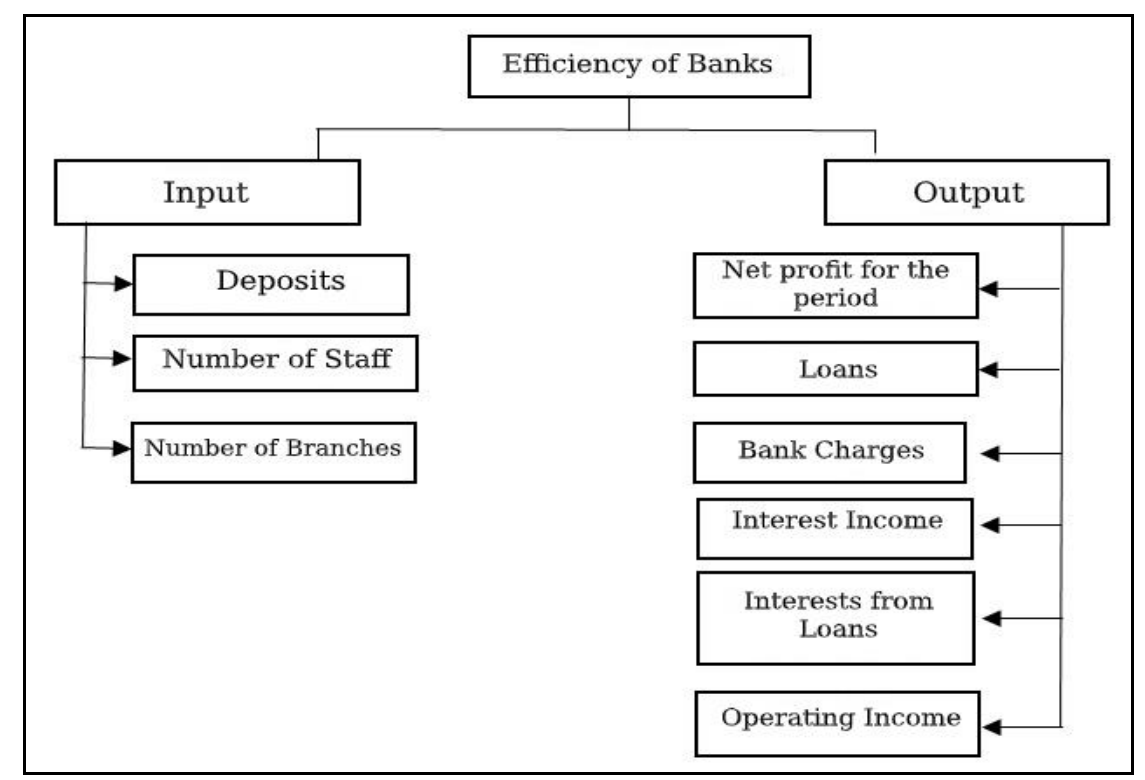

Figure no. 2. The AHP hierarchy 
The sub-hierarchies were compared with each other. The geometric mean of these evaluations was obtained and binary comparison matrix was formed.

The binary comparison of the input and output criteria according to the hierarchical order is given in the following matrix.

Decision matrix of inputs:

$$
\left[\begin{array}{cccc}
1 & 0,49 & 0,44 & 1,07 \\
2,04 & 1 & 0,54 & 2,09 \\
2,25 & 1,86 & 1 & 2,09 \\
0,93 & 0,48 & 0,48 & 1
\end{array}\right]_{4 \times 4}
$$

Decision matrix of outputs:

$\left[\begin{array}{cccccc}1 & 0,62 & 0,82 & 1,57 & 0,45 & 0,91 \\ 1,61 & 1 & 5,00 & 1,00 & 0,26 & 0,26 \\ 1,21 & 0,20 & 1 & 0,17 & 0,17 & 0,17 \\ 0,64 & 1,00 & 5,92 & 1 & 0,38 & 0,58 \\ 2,24 & 3,87 & 5,92 & 2,65 & 1 & 5,92 \\ 1,10 & 3,87 & 5,92 & 1,73 & 0,17 & 1\end{array}\right]_{6 x 6}$

Decision matrices were normalized to make binary comparisons feasible. Normalization was performed as follows:

$$
\begin{aligned}
& b_{i j}=\frac{a_{i j}}{\sum_{i=1}^{n} a_{i j j}} \\
& b_{11}=1 /(1+2.04+2.25+0.93)=0.16
\end{aligned}
$$

Normalized matrix for input after the operation:

$G_{\text {norm }}=\left[\begin{array}{llll}0,16 & 0,13 & 0,18 & 0,17 \\ 0,33 & 0,26 & 0,22 & 0,33 \\ 0,36 & 0,49 & 0,41 & 0,33 \\ 0,15 & 0,13 & 0,19 & 0,16\end{array}\right]_{4 \times 4}$

Normalized matrix for outputs was found to be as follows:

$$
\begin{aligned}
& b_{i j}=\frac{\sigma_{i j}}{\sum_{i=1}^{M} \sigma_{i j}} \\
& b_{11}=1 /(1.00+1.61+1.21+0.64+2.24+1.10)=0.13 \\
& G_{\text {norm }}=\left[\begin{array}{llllll}
0,13 & 0,06 & 0,03 & 0,19 & 0,18 & 0,10 \\
0,21 & 0,09 & 0,20 & 0,12 & 0,11 & 0,03 \\
0,16 & 0,02 & 0,04 & 0,02 & 0,07 & 0,02 \\
0,08 & 0,09 & 0,24 & 0,12 & 0,16 & 0,07 \\
0,29 & 0,37 & 0,24 & 0,33 & 0,41 & 0,67 \\
0,14 & 0,37 & 0,24 & 0,21 & 0,07 & 0,11
\end{array}\right]
\end{aligned}
$$

After the normalized matrix is calculated, the priority matrix is created. 
$W=\left[\begin{array}{c}w_{1} \\ w_{2} \\ \vdots \\ w_{n n}\end{array}\right]$

and

$w_{i}=\frac{\sum_{j=1}^{n} b_{i j}}{n}$

Priority vector for input:

$\mathrm{W}_{\text {one }}=\frac{0,16+0,12+0,18+0,17}{4}=0.16$

$W=\left[\begin{array}{l}0,19 \\ 0,28 \\ 0,40 \\ 0,16\end{array}\right]$

Here $\mathrm{w}_{1}=0.16$ indicates that the deposit account, one of the input criteria, has a $16 \%$ significance level for the bank's efficiency. The number of personnel has a significance level of $28 \%$, the number of branches has $40 \%$ and the shareholders' equity has $16 \%$ significance level. Similarly, the priority vector for outputs is as follows:

$\mathrm{W}_{\text {one }}=\frac{0,13+0,06+0,03+0,19+0,18+0,10}{6}=0.11$

$W=\left[\begin{array}{l}0,11 \\ 0,15 \\ 0,50 \\ 0,12 \\ 0,38 \\ 0,19\end{array}\right]$

In this matrix, net profit for the period is $11 \%$, loans are $15 \%$, commission is $50 \%$, interest income is $12 \%$, operating profit is $38 \%$ and interest from loans is $19 \%$ influential in banks' efficiency.

The sum of the values of the priority vector $\mathrm{W}$ column vector is equal to 1 . In the next step, it was analyzed whether the decision matrix we obtained from the opinions of the people we consulted with the expert opinions was consistent. If consistency is acceptable, the results should be evaluated by looking at the compliance rate for this procedure. Eigenvector is used for consistency calculation. When a square with real element $\mathrm{A}_{\mathrm{NxN}}$ matrix and non-zero $X_{\mathrm{nx} 1}$ the vector are considered; if there is a scalar that satisfies the equation $\mathrm{A} \mathrm{w}=1 \mathrm{w}$, this non-zero vector $\mathrm{w}$ is an eigenvector of the square matrix $\mathrm{A}$. I is defined as the eigenvalue of matrix A (Timor, 2011, p. 35). Saaty points out that A $w=1_{\max }$ $\mathrm{w}$ and $\mathrm{l}_{\max } \geq \mathrm{n}$ and specifies that if $\mathrm{l}_{\max } \mathrm{n}=\mathrm{A}$, the matrix $\mathrm{A}$ is consistent. If the deviation is up to 0,1 in calculation using $l_{\max }$, this can be considered consistent. In this study, the consistency calculation was performed as follows:

$A * w=\left[\begin{array}{lllll}a_{11} & \cdots & a_{1 j} \cdots & a_{1 n} \\ a_{i 1} & \cdots & a_{i j} & \cdots & a_{i n} \\ a_{n 1} & \cdots & a_{n j} & \cdots & a_{n n}\end{array}\right] x\left[\begin{array}{l}w_{1} \\ w_{2} \\ w_{n n}\end{array}\right]=\left[\begin{array}{l}s_{1} \\ s_{2} \\ s_{n}\end{array}\right]$ 
Eigenvalue Vector of Inputs:

$\mathrm{AW}=\left[\begin{array}{cccc}1 & 0,49 & 0,44 & 1,07 \\ 2,04 & 1 & 0,54 & 2,09 \\ 2,25 & 1,86 & 1 & 2,09 \\ 0,93 & 0,48 & 0,48 & 1\end{array}\right] *\left[\begin{array}{c}0,16 \\ 0,28 \\ 0,40 \\ 0,16\end{array}\right]=\left[\begin{array}{c}0,644772 \\ 1,154019 \\ 1,617399 \\ 0,634143\end{array}\right]$

$1_{\mathrm{I}}=\frac{\Sigma_{i}}{W_{i}} ; \lambda_{M a k s}=\frac{\sum_{i=1}^{n} \lambda_{i}}{n}$

$\lambda=\left[\begin{array}{l}4,027584 \\ 4,044552 \\ 4,073462 \\ 4,025617\end{array}\right]$

$\lambda_{\max }, \lambda$ is the average.

$\lambda_{\text {Maks }}=4.042804$

ompliance index:

$C I=\frac{\lambda_{M a k s}-n}{n-1}=\frac{4,042804-4}{4-1}=0,01$

If $\mathrm{RI}=0.89$ is taken from Table 2 for $\mathrm{n}=4$ criteria, the consistency ratio, $\mathrm{CR}$ is:

$C R=\frac{C I}{R I}=\frac{0,01}{0,89}<\% 10$

Since the CR ratio is less than 0.1 , the binary comparison matrix is consistent.

Eigenvalue Vector of Outputs S:

$A * W=S=\left[\begin{array}{cccccc}1 & 0,62 & 0,82 & 1,57 & 0,45 & 0,91 \\ 1,61 & 1 & 5,00 & 1,00 & 0,26 & 0,26 \\ 1,21 & 0,20 & 1 & 0,17 & 0,17 & 0,17 \\ 0,64 & 1,00 & 5,92 & 1 & 0,38 & 0,58 \\ 2,24 & 3,87 & 5,92 & 2,65 & 1 & 5,92 \\ 1,10 & 3,87 & 5,92 & 1,73 & 0,17 & 1\end{array}\right] *\left[\begin{array}{l}0,11 \\ 0,15 \\ 0,50 \\ 0,12 \\ 0,38 \\ 0,19\end{array}\right]=\left[\begin{array}{c}0,7852 \\ 0,8617 \\ 0,3402 \\ 0,9049 \\ 2,9233 \\ 1,4173\end{array}\right]$

$S_{i} / w_{i}=\lambda=\left[\begin{array}{l}6,7152 \\ 6,7711 \\ 6,2773 \\ 7,1242 \\ 7,6160 \\ 7,4313\end{array}\right]$

$\lambda_{\text {Maks }}=6.5879$

Compliance index:

$C I=\frac{6,5879-6}{6-1}=0,1175$ 
The Random Display is 1.25 for RI $\mathrm{n}=6$.

Consistency ratio:

$C R=\frac{C I}{R I}=\frac{0,1175}{1,25}=0,094$

Here again, the consistency ratio is consistent since CR is less than 0.1 . In this case, input and output weights obtained from AHP can be used in DEA. Frontier Analyst package program was used for DEA. 18 banks operating in Turkey, whose information we could access, were used as Decision Making Unit. Both input-oriented and output-oriented models were used in the analysis. First, analyzes were performed using both weighted and weightless models to demonstrate the importance of weighting. Both are shown in Table no 3. When Table no 3 is examined, it is seen that the weightless model is inadequate in ordering efficiency. For this reason, subsequent analyzes were performed on a weighted model.

Table no. 3. Weighted and unweighted CCR - BCC analysis of banks in 2017

\begin{tabular}{|c|c|c|c|c|c|c|}
\hline & \multicolumn{3}{|c|}{ Weightless Model } & \multicolumn{3}{|c|}{ Weighted Model } \\
\hline & $\mathrm{CCR}$ & $\mathrm{BCC}$ & \multirow{2}{*}{$\begin{array}{l}\text { Scale } \\
\text { Feature }\end{array}$} & $\mathrm{CCR}$ & $\mathrm{BCC}$ & \multirow{2}{*}{$\begin{array}{l}\text { Scale } \\
\text { Feature }\end{array}$} \\
\hline Banks & Score & Score & & Score & Score & \\
\hline Citibank Inc. & 100 & 100 & Constant & 100 & 100 & Constant \\
\hline Turkish Garanti Bank Inc. & 100 & 100 & Constant & 100 & 100 & Constant \\
\hline Turkish Vakıflar Bank & 100 & 100 & Constant & 96.4 & 100 & Constant \\
\hline ING Bank & 100 & 100 & Constant & 94.7 & 97.93 & Increased \\
\hline T.R. Ziraat Bank & 100 & 100 & Constant & 93.54 & 100 & Constant \\
\hline Turkish Halk Bank Inc. & 100 & 100 & Constant & 91.7 & 98.37 & Increased \\
\hline AKBANK Inc. & 100 & 100 & Constant & 90.61 & 100 & Constant \\
\hline Turkish Halk Bank Inc. & 100 & 100 & Constant & 86,13 & 88.45 & Increased \\
\hline Finans Bank Inc. & 100 & 100 & Constant & 81.66 & 92.59 & Increased \\
\hline Yapı ve Kredi Bank Inc. & 100 & 100 & Constant & 79.33 & 92.34 & Increased \\
\hline HSBC Bank Inc. & 100 & 100 & Constant & 71.98 & 87.24 & Increased \\
\hline Turkish Economy Bank Inc. & 100 & 100 & Constant & 71.4 & 81.21 & Increased \\
\hline Burgan Bank & 100 & 100 & Constant & 59.69 & 66.05 & Decreased \\
\hline Anadolubank Inc. & 100 & 100 & Constant & 53.89 & 56.75 & Increased \\
\hline Denizbank A.Ş. & 100 & 100 & Constant & 52.09 & 62.33 & Increased \\
\hline Alternatif Bank & 95.62 & 97.03 & Decreased & 41.9 & 49.14 & Decreased \\
\hline Şekerbank T.A.Ş. & 91.96 & 100 & Constant & 27.95 & 29,73 & Decreased \\
\hline TurkishBank & 79.4 & 100 & Constant & 17.88 & 100 & Constant \\
\hline
\end{tabular}

When analysis is based on Weighted Input Oriented CCR model, the analysis of the data of 2017 in Table no 3, it is seen that only two banks out of the 18 banks are fully efficient and the others are not efficient. In the BCC model analysis showing local efficiency, it was observed that 5 other banks were not efficient. Weighted input oriented CCR analysis for Vakıfbank in 2017 is presented in Figure no. 3.

In order to be efficient, Vakıfbank, which is not fully efficient but locally efficient, should make potential improvements given in Table no 4. 


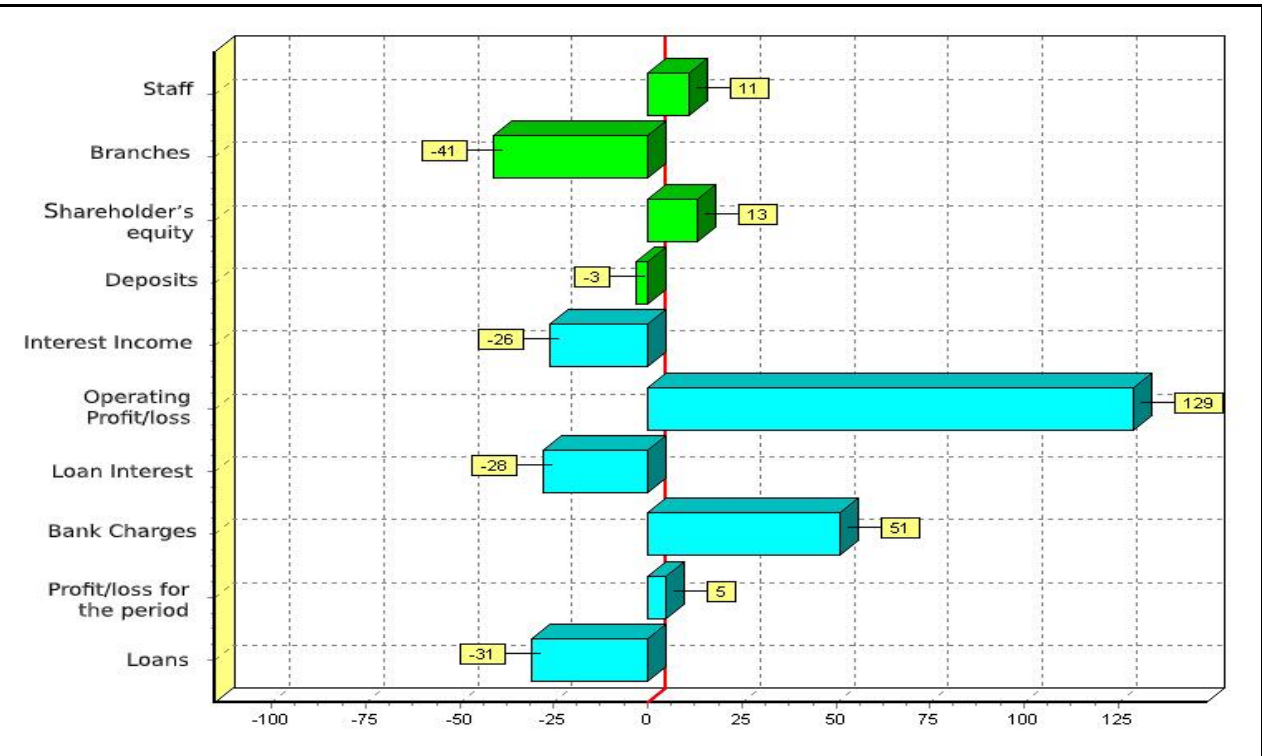

Figure no. 3. Weighted input oriented CCR analysis for Vakıfbank for 2017

Table no. 4. Input and output oriented weighted CCR potential improvement analysis for vakıfbank for 2017

\begin{tabular}{|c|c|c|c|c|c|c|c|}
\hline \multirow{2}{*}{\multicolumn{2}{|c|}{$\begin{array}{c}\text { DMU } \\
\text { VAKIFBANK }\end{array}$}} & \multicolumn{3}{|c|}{ OUTPUT ORIENTED MODEL } & \multicolumn{3}{|c|}{ INPUT-ORIENTED MODEL } \\
\hline & & $\begin{array}{c}\text { Actual } \\
\text { Value }\end{array}$ & $\begin{array}{c}\text { Objective } \\
\text { Value }\end{array}$ & $\begin{array}{c}\text { Potential } \\
\text { Improvement }\end{array}$ & $\begin{array}{l}\text { Actual } \\
\text { Value }\end{array}$ & $\begin{array}{c}\text { Objective } \\
\text { Value }\end{array}$ & $\begin{array}{c}\text { Potential } \\
\text { Improvement }\end{array}$ \\
\hline \multirow{4}{*}{ 忩 } & Personnel & 16097 & 17364.2 & 7.87 & 16097 & 18013.43 & 11.91 \\
\hline & Branch & 927 & 522.04 & -43.68 & 927 & 541.56 & -41.58 \\
\hline & Equity & 23258 & 25467.1 & 9.5 & 23258 & 26419.27 & 13.59 \\
\hline & Bank deposit & $\begin{array}{l}155 \\
277\end{array}$ & 144797 & -6.75 & 155277 & $150,210.3$ & -3.26 \\
\hline \multirow{6}{*}{ 里 } & \begin{tabular}{|l} 
Interest \\
income
\end{tabular} & 8621 & 6079.05 & -29.49 & 8621 & 6306.33 & -26.85 \\
\hline & \begin{tabular}{|l|} 
Operating \\
Profit / Loss
\end{tabular} & 4675 & 10356.5 & 121.53 & 4675 & 10743.66 & 129.81 \\
\hline & Loan interest & 18263 & 12655.2 & -30.71 & 18263 & 13128.36 & -28.12 \\
\hline & Commission & 2000 & 2919.95 & 46 & 2000 & 3029.12 & 51.46 \\
\hline & $\begin{array}{l}\text { Profit and } \\
\text { Loss for the } \\
\text { Period }\end{array}$ & 3723 & 3799.33 & 2.05 & 3723 & 3941.39 & 5.87 \\
\hline & \begin{tabular}{|l|} 
Loans \\
\end{tabular} & 183972 & 120982 & -34.24 & 183972 & $125,505.6$ & -31.78 \\
\hline
\end{tabular}


If the potential improvement rates of VakıfBank are analyzed, the same outputs as given in Figure no 4 should increase the number of personnel as one of the input criteria by $11.91 \%$ and increase Equity by $13.59 \%$ and reduce the number of branches by $41.58 \%$ and $3.26 \%$. In the outputs, it is stated that it has the potential to decrease interest income by $26.85 \%$, credit interest by $28.12 \%$, loans by $31.78 \%$ and increase operating profit by $129.81 \%$ and period profit by $5.87 \%$.

When Weighted Output Oriented CCR model is analyzed, VakıfBank should reduce the number of branches as one of the inputs by $43.48 \%$, deposits by $6.75 \%$ and increase the number of personnel by $7.87 \%$ and shareholders' equity by $9.5 \%$. In the outputs, interest income should be reduced by $29.49 \%$, credit interest by $30.71 \%$, loans by $34.24 \%$, while operating profit should be increased by $121.53 \%$, commission by $46 \%$ and net period profit by $2.05 \%$.

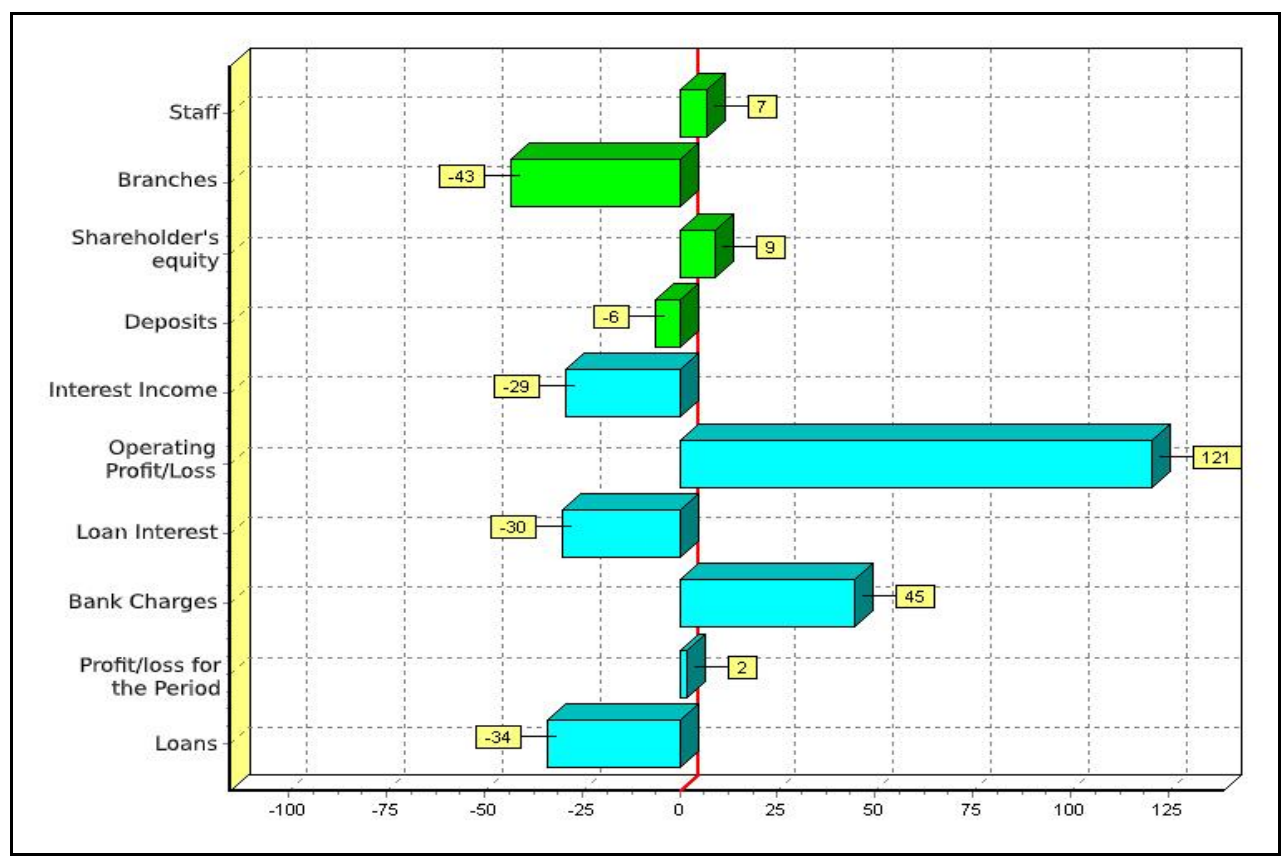

Figure no. 4. Output oriented weighted CCR analysis for Vakıfbank for 2017

Input and output oriented weighted CCR analysis for potential improvement of inefficient banks in 2017 are presented in Table no. 5 ( $\mathrm{a}$ and $\mathrm{b}$ ) 
Table no. 5a. Input and output oriented weighted CCR analysis for potential improvement of inefficient banks in 2017

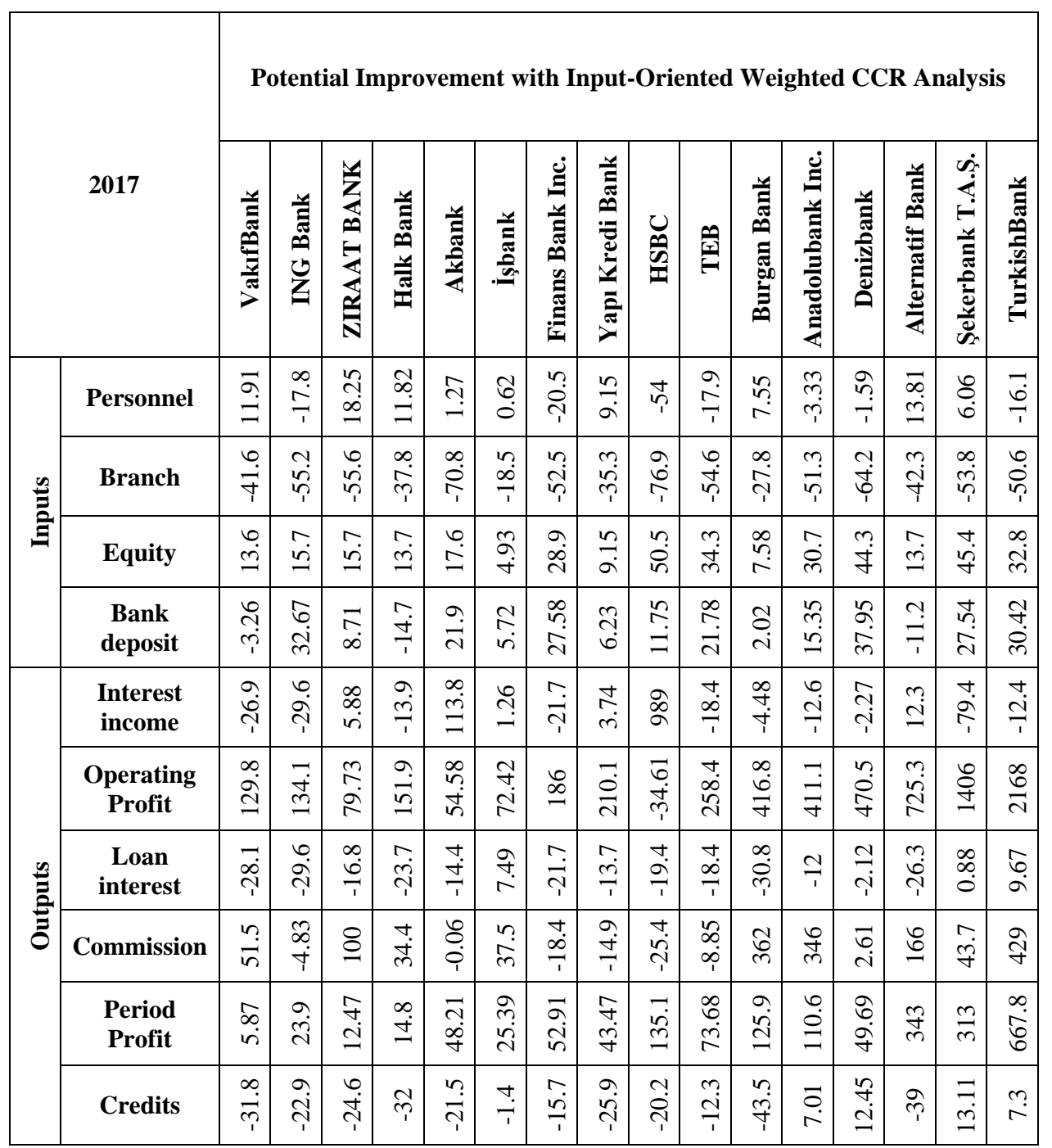


Table no. 5b. Input and output oriented weighted CCR analysis for potential improvement of inefficient banks in 2017

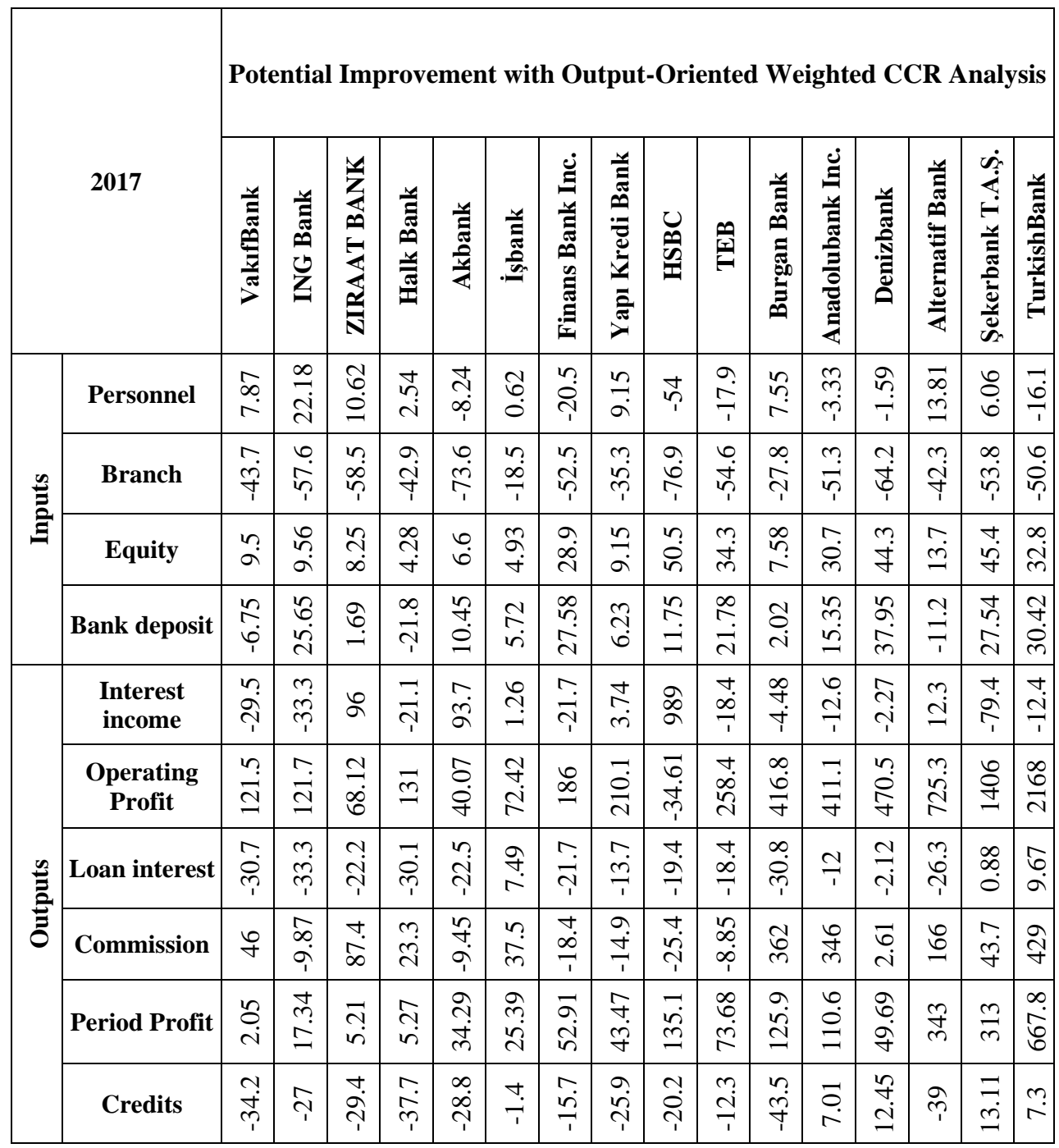

Suggestions for it to be fully efficient are given in Table no. $6(a, b, c)$. 
Table no. 6a. Efficiency results of banks between 2008-2010

\begin{tabular}{|c|c|c|c|c|c|c|c|c|c|}
\hline Years & \multicolumn{3}{|c|}{2008} & \multicolumn{3}{|c|}{2009} & \multicolumn{3}{|c|}{2010} \\
\hline \multirow[t]{2}{*}{ Banks } & \multirow[t]{2}{*}{ CCR } & \multirow[t]{2}{*}{ BCC } & $\begin{array}{c}\text { Scale } \\
\text { Feature }\end{array}$ & \multirow[t]{2}{*}{ CCR } & \multirow[t]{2}{*}{ BCC } & \multirow{2}{*}{$\begin{array}{c}\text { Scale } \\
\text { Feature } \\
\text { Feature } \\
\end{array}$} & \multirow[t]{2}{*}{ CCR } & \multirow[t]{2}{*}{ BCC } & $\begin{array}{c}\text { Scale } \\
\text { Feature }\end{array}$ \\
\hline & & & Feature & & & & & & Feature \\
\hline Citibank Inc. & 45.78 & 60.74 & Decreased & 61.21 & 93.49 & Decreased & 45.78 & 60.74 & Decreased \\
\hline Garanti Bank & 100 & 100 & Constant & 100 & 100 & Constant & 100 & 100 & Constant \\
\hline VakıfBank & 97.11 & 97.58 & Increased & 97.64 & 97.74 & Decreased & 97.11 & 97.58 & Decreased \\
\hline ING Bank & 69.41 & 70.07 & Decreased & 71.76 & 72.75 & Decreased & 69.41 & 70.07 & Decreased \\
\hline Ziraat bank & 95.55 & 100 & Constant & 98.69 & 100 & Constant & 95.55 & 100 & Constant \\
\hline Halkbank & 100 & 100 & Constant & 100 & 100 & Constant & 100 & 100 & Constant \\
\hline Akbank & 99.86 & 100 & Constant & 93.96 & 94.06 & Constant & 99.86 & 100 & Constant \\
\hline İş Bank & 87.06 & 100 & Constant & 84.22 & 99.01 & Increased & 87.06 & 100 & Constant \\
\hline Finans Bank & 97.93 & 97.95 & Increased & 89.43 & 89.77 & Constant & 97.93 & 97.95 & Increased \\
\hline Yap1 Kredi & 94.55 & 94.6 & Decreased & 95.87 & 96 & Constant & 94.55 & 94.6 & Decreased \\
\hline HSBC Bank & 94.62 & 95.56 & Decreased & 75.34 & 77.12 & Constant & 94.62 & 95.56 & Decreased \\
\hline TEB & 72.86 & 73.12 & Decreased & 68.14 & 69.87 & Constant & 72.86 & 73.12 & Decreased \\
\hline Burgan Bank & 45.59 & 69.56 & Decreased & 45.92 & 97.84 & Constant & 45.59 & 69.56 & Decreased \\
\hline Anadolubank & 95.8 & 100 & Constant & 85.45 & 96.54 & Constant & 27.58 & 100 & Decreased \\
\hline Denizbank & 76.79 & 77.58 & Decreased & 95.73 & 95.88 & Constant & 76.79 & 77.58 & Decreased \\
\hline $\begin{array}{l}\text { Alternatif } \\
\text { Bank }\end{array}$ & 99.43 & 100 & Constant & 93.9 & 100 & Constant & 99.43 & 100 & Decreased \\
\hline Şekerbank & 78.36 & 79.23 & Decreased & 66.11 & 66.92 & Constant & 78.36 & 79.23 & Decreased \\
\hline TurkishBank & 27.58 & 100 & Constant & 14.17 & 100 & Constant & 27.58 & 100 & Decreased \\
\hline
\end{tabular}

Table no. 6b. Efficiency results of banks between 2011-2013

\begin{tabular}{|c|c|c|c|c|c|c|c|c|c|}
\hline Years & \multicolumn{3}{|c|}{2011} & \multicolumn{3}{|c|}{2012} & \multicolumn{3}{|c|}{2013} \\
\hline \multirow[t]{2}{*}{ Banks } & \multirow[t]{2}{*}{ CCR } & \multirow[t]{2}{*}{ BCC } & \multirow{2}{*}{$\begin{array}{c}\text { Scale } \\
\text { Feature } \\
\text { Feature }\end{array}$} & \multirow[t]{2}{*}{ CCR } & \multirow[t]{2}{*}{ BCC } & \multirow{2}{*}{$\begin{array}{c}\text { Scale } \\
\text { Feature } \\
\text { Feature } \\
\end{array}$} & \multirow[t]{2}{*}{ CCR } & \multirow[t]{2}{*}{ BCC } & $\begin{array}{c}\text { Scale } \\
\text { Feature }\end{array}$ \\
\hline & & & & & & & & & Feature \\
\hline Citibank Inc. & 34.04 & 50.63 & Decreased & 33.77 & 39.37 & Decreased & 45.78 & 60.74 & Decreased \\
\hline Garanti Bank & 100 & 100 & Constant & 63.6 & 100 & Increased & 100 & 100 & Constant \\
\hline VakıfBank & 100 & 100 & Constant & 54.04 & 93.8 & Decreased & 97.11 & 97.58 & Decreased \\
\hline ING Bank & 67.38 & 69.13 & Decreased & 48.36 & 60.19 & Decreased & 69.41 & 70.07 & Decreased \\
\hline Ziraat bank & 89.35 & 100 & Increased & 43.5 & 100 & Increased & 95.55 & 100 & Constant \\
\hline Halkbank & 100 & 100 & Increased & 64.24 & 100 & Increased & 100 & 100 & Constant \\
\hline Akbank & 52.7 & 52.72 & Increased & 57.29 & 98.73 & Decreased & 99.86 & 100 & Constant \\
\hline İş Bank & 82.35 & 100 & Constant & 62.35 & 100 & Increased & 87.06 & 100 & Constant \\
\hline Finans Bank & 100 & 100 & Constant & 59.84 & 87.95 & Decreased & 97.93 & 97.95 & Increased \\
\hline Yapı Kredi & 61.74 & 63.11 & Increased & 44.68 & 100 & Increased & 94.55 & 94.6 & Decreased \\
\hline HSBC Bank & 80.46 & 82.67 & Increased & 43.93 & 52.4 & Decreased & 94.62 & 95.56 & Decreased \\
\hline TEB & 71.2 & 71.61 & Increased & 58.05 & 75.39 & Decreased & 72.86 & 73.12 & Decreased \\
\hline Burgan Bank & 51.74 & 66.07 & Increased & 12.85 & 19.28 & Decreased & 45.59 & 69.56 & Decreased \\
\hline Anadolubank & 72.47 & 81.68 & Increased & 39.41 & 44.31 & Decreased & 95.8 & 100 & Constant \\
\hline Denizbank & 86.77 & 88.7 & Increased & 60.3 & 76.52 & Decreased & 76.79 & 77.58 & Decreased \\
\hline $\begin{array}{l}\text { Alternatif } \\
\text { Bank }\end{array}$ & 88.23 & 100 & Increased & 56.74 & 82.82 & Decreased & 99.43 & 100 & Constant \\
\hline Şekerbank & 69.48 & 70.86 & Increased & 53.27 & 53.29 & Decreased & 78.36 & 79.23 & Decreased \\
\hline TurkishBank & 27.58 & 100 & Constant & 14.17 & 100 & Decreased & 27.58 & 100 & Constant \\
\hline
\end{tabular}


Table no. 6c. Efficiency results of banks between 2014-2017

\begin{tabular}{|c|c|c|c|c|c|c|c|c|c|c|c|c|}
\hline Years & \multicolumn{3}{|c|}{2014} & \multicolumn{3}{|c|}{2015} & \multicolumn{3}{|c|}{2016} & \multicolumn{3}{|c|}{2017} \\
\hline \multirow{2}{*}{ Banks } & \multirow{2}{*}{ CCR } & \multirow{2}{*}{ BCC } & $\begin{array}{c}\text { Scale } \\
\text { Feature }\end{array}$ & \multirow{2}{*}{ CCR } & \multirow{2}{*}{ BCC } & \multirow{2}{*}{$\begin{array}{c}\text { Scale } \\
\text { Feature } \\
\text { Feature }\end{array}$} & \multirow{2}{*}{ CCR } & \multirow{2}{*}{ BCC } & \multirow{2}{*}{\begin{tabular}{|c|}
$\begin{array}{c}\text { Scale } \\
\text { Feature }\end{array}$ \\
Feature \\
\end{tabular}} & \multirow{2}{*}{ CCR } & \multirow{2}{*}{ BCC } & $\begin{array}{c}\text { Scale } \\
\text { Feature }\end{array}$ \\
\hline & & & Feature & & & & & & & & & Feature \\
\hline nc. & 34.04 & 50.63 & Decreased & 77 & 39.37 & Decreased & 45.78 & 60.74 & Decreased & 100 & 100 & Constant \\
\hline Garanti Bank & 100 & 100 & Cons & 63.6 & 100 & Increased & 100 & 100 & Constant & 100 & 100 & ant \\
\hline VakıfBank & 100 & 100 & ant & 54.04 & 93.8 & Decreased & 97.11 & 97.58 & Decreased & 96.4 & 100 & $\operatorname{tant}$ \\
\hline ING Bank & 67.38 & 69.13 & Decr & 48.36 & 60.19 & Decreased & 69.41 & 70.07 & Decreased & 94.7 & 97.99 & Incr \\
\hline Ziraat bank & 89.35 & 100 & Increased & 43.5 & 100 & Increased & 95.55 & 100 & Constant & 93.54 & 100 & $\tan t$ \\
\hline Halkbank & 100 & 100 & Increased & 64.24 & 100 & Increased & 100 & 100 & Constant & 91.7 & 98.59 & Increased \\
\hline Akbank & 52.7 & 52.72 & Increased & 57.29 & 98.73 & Decreased & 99.86 & 100 & Constant & 90.61 & 100 & Constant \\
\hline İş Bank & 82.35 & 100 & Con & 62.35 & 100 & Increased & 87.06 & 100 & Con & 86.13 & 91.41 & Inc1 \\
\hline Finans B & 100 & 100 & Constant & 59.84 & 87.95 & Decreased & 97.93 & 97.95 & Increased & 81.66 & 92.73 & sed \\
\hline Yap1 Kredi & 61.74 & 63.11 & Increased & 44.68 & 100 & Increased & 94.55 & 94.6 & Decreased & 79.33 & 92.55 & Incr \\
\hline HSBC Bank & 80.46 & 82.67 & Increased & 43.93 & 52.4 & Decreased & 94.62 & 95.56 & Decreased & 71.98 & 89.01 & Increased \\
\hline TEB & 71.2 & 71.61 & Incr & 58.05 & 75.39 & Decreased & 72.86 & 73.12 & Decreased & 71.4 & 81.77 & ased \\
\hline Burgar & 51.74 & 66.07 & Increased & 12.85 & 19.28 & Decreased & 45.59 & 69.56 & Decreased & 59.69 & 60.83 & eased \\
\hline Anadolubank & 72.47 & 81.68 & Increased & 39.41 & 44.31 & Decreased & 95.8 & 100 & Constant & 53.89 & 54.69 & Dec \\
\hline Denizbank & 86.77 & 88.7 & sed & 60.3 & 76.52 & Decreased & 76.79 & 77.58 & Decreased & 52.09 & 64.9 & Increased \\
\hline $\begin{array}{l}\text { Alternatif } \\
\text { Bank }\end{array}$ & 88.23 & 100 & Increased & 56.74 & 82.82 & Decreased & 99.43 & 100 & 20 & 41.9 & 42.21 & In \\
\hline Şekerbank & 69.48 & 70.86 & ed & 53.27 & 53.29 & Decreased & 78.36 & 79.23 & sed & 27.95 & 31.53 & Inc \\
\hline TurkishBank & 27.58 & 100 & Constant & 14.17 & 100 & Decreased & 27.58 & 100 & Constant & 17.88 & 100 & Constant \\
\hline
\end{tabular}

\section{Conclusions}

A strong and solid economy is ensured by a working and growing financial system. The banking system is at the center of the Turkish financial system. This is due to the fact that most of the financial resources are collected and used by banks. In the efficient and healthy operation of the banking sector, it is important to reach implications via the following the economic situation in the world and the making right analyzes. In order to ensure high performance in the banking sector, the productivity and efficiency of all components of the enterprise must be ensured. When conducting this performance assessment, it is necessary to analyze with appropriate measurements. The competitive environment that exists in the whole sector requires the most efficient use of resources. Performance and efficiency evaluation results are important to determine the level of resources to be used. AHP-based DEA evaluation has been prominent in the evaluation of efficiency in the literature.

Targets have been determined on how banks should change their input and output values in order to reach the efficiency frontier. The purpose of this study is to shed light on future policies administrators of incorporation can apply, on the amount of input-output to be used, and on the potential improvements necessary for the inefficient enterprises to become efficient using DEA, which is an efficiency measurement method without a parameter. It is used to measure the relative efficiency in multi-criteria analysis.

The analysis was made on 18 banks in the banking sector in Turkey, whose data could be accessed the criteria used in the bank analysis were weighted with the help of AHP and the efficiency of the banks was evaluated consistently. At the same time, it was shown that the results of weighted analyzes were more accurate by comparing the analyzes made with weighting and the analyzes made without weighting. 
As a result of the analysis, Garanti Bank succeeded to be efficient in all years except for 2012 and became the reference bank in the Turkish banking sector. Citibank, which failed to achieve efficiency between 2008-2013, became a reference bank by being fully efficient between 2014-2017. Fully efficient in 2011 and 2016, VakıfBank did not achieve efficiency despite being close to efficiency frontier in the other years in that period. However, after 2014, it has managed to be locally efficient. The result of this analysis was evaluated to result from the fact that VakıfBank, which is actually a foundation enterprise, could not reach its full efficiency due to being open to the bank the government's intervention because of the economic difficulties experienced in Turkey in recent years. Ziraat Bank, which has an important place in the Turkish economy, has been efficient in 2015 , while it has been locally productive in all years. The fact that this bank was also open to government intervention bank was interpreted as the biggest factor for its not being able to achieve full efficiency. Halkbank, on the other hand, managed to be locally efficient between 2008-2013 and fully efficient in 2010, 2011, 2013. After 2014, it lost its efficiency. This was thought to have stemmed from the bank about the negative developments after 2014 in Turkey and in America. Akbank belonging to one of the major conglomerates in Turkey was locally efficient in 2008, 2010, 2013, and in 2014. It has never been fully efficient during this time period. Suggestions for it to be fully efficient are given in Table 6 (a1, a2, a3). Turkish Bank, which started operations in Turkey in 1982, could not achieve full efficiency despite being constantly efficient locally.

When the banking sector becomes independent, achieving full efficiency increases. When the external impacts on the sector increase, they move away from being fully efficient even if they are locally efficient.

\section{References}

Afriat, S., 1972. Efficiency estimation of production functions. International Economic Review, 13(3), pp.568-598.

Alp, S. and Gündoğdu, C.E., 2012. Analytical Hierarchy Process and Application of Fuzzy Analytic Hierarchy Process in Site Selection. Dokuz Eylül University. Journal of the Institute of Social Sciences, 14(1), pp.7-25.

Basar, A., Kabak, O. and Topçu, Y.İ., 2015. A Tabu Search Algorithm for Multi-Period Bank Branch Location Problem: A Case Study in a Turkish Bank. Scientia Iranica. 26(3), pp.3728-3746.

Berger, A.N., 2007. International Comparisons of Banking Efficiency. Financial Markets, Institutions \& Instruments, 16, pp.119-144.

Charnes, A. and Cooper, W.W., 1962. Programming with Linear Fractional Functions. Naval Research Logistic Quarterly, 9(3-4), pp.181-186.

Charnes, A., Cooper, W.W. and Rhodes, E., 1978. Measuring the Efficiency of DecisionMaking Units. European Journal of Operations Research, 2(6), pp.429-444.

Cingi, S. and Güran, M.C., 2002. Efficiency of Economic Interventions of Government. Akdeniz IIBBF Dergis, 2(3), pp.56-90.

Coelli, T., 1996. A Guide to DEAP Version 2.1: A Data Envelopment Analysis (Computer) Program Working. Working Paper. Maine: University of New England. 
Çaymak, Ş. and Çaymak, D., 2017. Sağlık Hizmetlerinde Etkinlik Kavramı. Să̆lık Yönetimi Dergisi, 1(1), pp.21-34.

Dehaene, S., 1997. The Number Sense: How the Mind Creates Mathematics. New York: Oxford University Press Inc.

Dikmen, F.C., 2008. Efficiency Measurement of The Universities with Data Envelopment Analysis. Kocaeli University. Journal of Faculty of Economics and Administrative Sciences, 3(6), pp.1-22.

Farrell, M.J., 1957. The measurement of productive efficiency. Journal of the Royal Statistical Society, 120 (3), pp.253-281.

Levine, R., 1997. Financial Development and Economic Growth: Views and Agenda. Journal of Economic Literature, 35(2), pp. 688-726.

Liu, H., 2007. Probablity distribution of dependency distance. Glottometrics, 15, pp.1-12.

Özbek, A. and Tamer, E., 2012. Determination of Third-Party Logistics (3PL) by Analytical Hierarchy Process (AHS). International Journal of Engineering Research and Development, 4(2), pp.46-54.

Saaty, T.L., 1982. Decision Making for Leaders; The Analytical Hierarchy Process for Decisions in a Complex World. Pittsburgh: RWS Publications.

Savaş, F., 2015. Çok Kriterli Karar Verme Yöntemleri. Ankara: Pegem Yayınları.

Taşkın, F.D., 2011. Factors Affecting the Performance of Commercial Banks in Turkey. Journal of Ege Academic View, 11(2), pp.289-298.

Timor, M., 2011. Analitik Hiyerarşi Prosesi. İstanbul: Türkmen Kitabevi. 